\title{
Molecular analysis of reticulocyte binding protein-2 gene in Plasmodium vivax isolates from India
}

\author{
Surendra K Prajapati*, Pragati Kumari and Om P Singh
}

\begin{abstract}
Background: Plasmodium vivax reticulocyte binding protein-2 (PVRBP-2) is a promising candidate for development of vaccine against parasite. DNA sequence polymorphism in pvrbp-2 which may hamper the vaccine development program has been identified in laboratory strains. Therefore, unraveling genetic polymorphism in pvrbp-2 from field isolates is a prerequisite for success in vaccine development. This study was designed with a primary aim to uncover genetic polymorphism in pvrbp-2 among $P$. vivax field isolates.

Results: Using virtual restriction mapping of pvrbp-2 sequences, two restriction enzymes (Alul and Apol) were selected for the development of pvrbp-2 as a PCR-RFLP marker. Restriction fragment length polymorphism (RFLP) analysis revealed a high degree of genetic polymorphism in the pvrbp-2 gene among field isolates of $P$. vivax. Apol-RFLP was found to be more efficient in identifying the extent of genetic polymorphism in pvrbp-2 compared to Alul-RFLP. Combined genotyping/haplotyping of RFLP pattern revealed a total of 36 distinct RFLP patterns among 83 P. vivax isolates analyzed. DNA sequence analysis also supports high degree of genetic polymorphism among field isolates of P. vivax. Pvrbp-2 PCR-RFLP method is able to distinguish multiple infection up to $16.86 \%$ and it revealed a low level of shared genetic pool between more than two populations.

Conclusion: The study suggests that pvrbp-2 is highly polymorphic genetic marker which can be used for population genetic analyses. RFLP analysis suggests presence of nearly similar proportion of Sal-1 and Belem alleles in Indian P. vivax populations. The larger extent of genetic polymorphism identified from limited samples advocates to screen genetic polymorphism in purbp-2 from malaria endemic geographical regions and countries for designing pvrbp-2 based anti-malarial control measures.
\end{abstract}

\section{Background}

Plasmodium vivax is the most widely distributed human malaria parasite outside sub Sahara regions of Africa. Although mild with its prolonged and recurrent infection resulting in huge morbidity, the species can also be severe and fatal [1-6]. Annual burden is estimated to be about 70-80 million cases globally [7], however in India, $P$. vivax is responsible for about one million malaria cases annually, contributing $50-55 \%$ of total malaria cases.

Using molecular techniques, genetic diversity studies of malaria parasites accelerated substantially and provided a landmark in understanding parasite genetic diversity, evolution of pathogenicity and drug resistance, and transmission success. Identifying highly polymorphic

\footnotetext{
* Correspondence: surendramrc@gmail.com

* Correspondence: surendramrc@gmail.com
Molecular Biology Division, National Institute of Malaria Research (NIMR), Sector 8, Dwarka, Delhi, India
}

marker is essential for studying genetic diversity, population structure, multiplicity of infection, and relapse and recrudescence infection etc. Till date, two types of molecular markers are in frequent use to unraveled genetic diversity from field isolates of $P$. vivax, these are tandem repeats markers $[8,9]$ and antigen encoding genes [10-12].

Invasion of erythrocytes by malaria parasite is a complex and multi-step process. Merozoites of $P$. vivax primarily invade the reticulocytes [13] whereas $P$. falciparum can invade both mature RBC as well as reticulocytes [14,15]. The specificity in binding with reticulocytes is mediated by a set of proteins which are encoded by a gene family called reticulocyte binding protein where members of this family are found in malaria parasites of human, simian and rodent [16-19]. The major function of reticulocyte binding protein is seen during the initial steps of erythrocyte selection and invasion [17]. Evidence suggests that the 
PvRBPs form a complex at the apical pole of the merozoite and confer the reticulocyte-specificity of $P$. vivax blood-stage infections, suggesting the essential role of RBP-II in selection and identification of reticulocyte for invasion [17]. Two pvrbp-2 genes have been characterized from $P$. vivax and are shown to be a promising vaccine candidate [20]; however, up to 12 putative pvrbp genes have been identified in $P$. vivax genome so far [21].

Pvrbp-2 is a promising vaccine target for the development of effective anti-malarial control measures [20]. However, genetic polymorphism at pvrbp-2 may hamper the efficacy of vaccine [22]. Therefore, investigation of genetic polymorphism at pvrbp-2 from geographical field isolates is an essential step. This study was designed to investigate the genetic polymorphism in pvrbp-2 using PCR-RFLP method in $P$. vivax field isolates from Indian subcontinent.

\section{Methods}

\section{Ethics statement}

This study was approved by the Ethics Committee of the National Institute of Malaria Research and all blood spots were collected with written consent of the patients and/or their legal guardians.

\section{Parasite collection and DNA extraction}

Ninety $P$. vivax field isolates collected between 20032006 from six geographical regions of the Indian subcontinent were analyzed (Figure 1). Finger prick blood from the symptomatic patients in active case detection surveys as well as from patient attending the clinics, was spotted on autoclaved Whatman filter paper strips (Number 3). The six geographical regions are Delhi $(\mathrm{N}=13)$, Nadiad of Gujarat $(\mathrm{N}=26)$, Panna of Madhya Pradesh $(\mathrm{N}=18)$, Rourkela of Odisa $(\mathrm{N}=16)$, Chennai of Tamil Nadu ( $\mathrm{N}=10)$, and Kamrup of Assam $(\mathrm{N}=7)$. Details of individual study sites such as location, parasite and vector species prevalence, and disease transmission pattern are reported elsewhere [23] as well as given in Additional file 1. Genomic DNA was isolated from microscopically diagnosed vivax-positive blood spotted on Whatman filter paper (3 $\mathrm{mm}$ ) strips using QIAamp mini DNA kit (Qiagen, Germany). Three punches (5 mm diameter) of dried blood spots were used for DNA isolation, as per the manufacturer's instructions. DNA was eluted in $120 \mu \mathrm{l}$ triple distilled autoclaved water and stored at $-20^{\circ} \mathrm{C}$ for future use.

\section{Primer designing and PCR amplification}

Nested PCR primers for pvrbp-2 gene were designed manually using pvrbp-2 sequence available in GenBank (AY501887). These primers are RBP2-F (5'-gatgatcaatttttatgcctgac-3'), RBP2-R (5'-cagaatccgcaataatagag-3'), RBP2-
NF (5'-ttcccgcacacacaaggtag-3'), RBP2-NR (5'-gcgtagtgtttagctgccac-3'), RBP2-IR1 (5'-tggaaccgtatgcgattc-3') and RBP2-IR2 (5'-ttttgcagataagatagc-3'). Internal primers used for sequencing this fragment are IR1 and IR2 and the schematic diagram of gene showing location of primers is given in Figure 2. Optimized PCR conditions for primary PCR for amplification of pvrbp-2 were:-initial denaturation $95^{\circ} \mathrm{C} / 5$ minute, denaturation $95^{\circ} \mathrm{C} / 30 \mathrm{~S}$ annealing $50^{\circ} \mathrm{C} / 30 \mathrm{~S}$ and extension at $68^{\circ} \mathrm{C} / 2$ minute for 35 cycles, and a final extension of $68^{\circ} \mathrm{C} / 5$ minute. The cycling conditions of nested PCR were similar to primary PCR except annealing temperature, which was $55^{\circ} \mathrm{C}$. All PCR amplifications were carried out in a $20 \mu \mathrm{l}$ reactions volume (Qiagen's Master Mix) with $10 \mathrm{pM}$ of each primer and.1-2 $\mu \mathrm{l}(\sim 3-5 \mathrm{ng})$ of genomic DNA in primary PCR and $0.5-1 \mu \mathrm{l}$ of primary PCR product in nested PCR.

\section{Restriction Fragment Length Polymorphism (RFLP)}

To determine the level of pvrbp-2 polymorphism, RFLP analysis was carried out using two restriction enzymes ApoI and AluI (NEB Inc, USA). These enzymes were selected on the basis of maximum probability of enzymes cutting sites in the polymorphic region of pvrbp-2 and the feasibility to resolve digested PCR fragment on agarose gel. Virtual restriction mapping of pvrbp-2 was done using SeqBuilder module of DNA Lasergene 7.1 software for identification of suitable restriction enzymes for RFLP study. Four microliters of PCR product was digested with individual restriction enzyme. AluI digestion was incubated at $37^{\circ} \mathrm{C}$ for 4 hours whereas $A p o$ I was incubated at $50^{\circ} \mathrm{C}$ for overnight. In both digestions, heat inactivation for enzymes was given at $80^{\circ} \mathrm{C} / 20$ minutes. The restriction products were visualized on a $2.5 \%$ agarose gel containing ethidium bromide. A consistent current at $0.75 \mathrm{~m}$ for $2.5 \mathrm{hrs}$ were used for all agarose gel electrophoresis experiments to achieve consistency in RFLP fragment sizes.

\section{RFLP Genotyping and multiple infection typing}

Digested DNA fragments were assessed using Genetool software and all fragments were considered for genotyping of RFLP data. In RFLP analysis, the restriction pattern of each enzyme was typed where each different/ unique RFLP pattern was assigned $1 \ldots \mathrm{n}$ as an allele. Finally, RFLP patterns of ApoI and AluI from each sample were combined to make a "haplotype or genotype". This "haplotyping/ genotyping" method provides a high-resolution power for differentiating parasites compared with RFLP pattern of individual enzyme.

Multiple infection could only be detected by RFLP analysis since all samples show only a single PCR fragment. A sample was considered as multi-clone infection if the sum of the digested fragments (either ApoI 


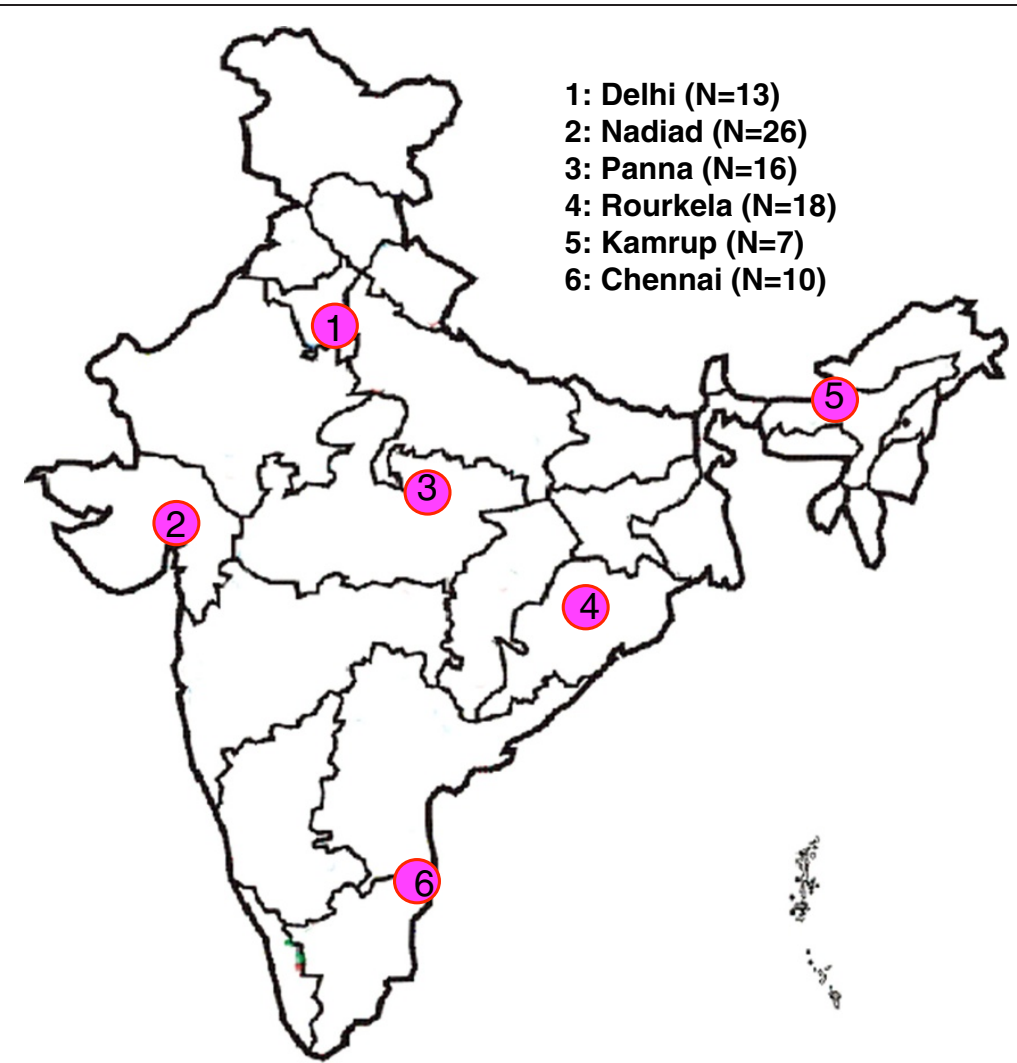

Figure 1 Map of India showing study sites. $\mathrm{N}$ indicates number of sample from individual geographical region.

or AluI or both) size is greater than the size of the PCR fragment.

\section{Cloning, DNA sequencing, and sequence analysis}

DNA sequencing of limited samples was done in order to validate RFLP pattern as well as to differentiate Sal-1 and Belem alleles of purbp-2. PCR products from 13 samples (Nadiad; 7, Delhi; 1, Kamrup; 2, and Panna; 3) were purified using gel extraction kit (MDI, India) and cloned in pTZ257R/T vector (Fermentas, USA). Six of 13 samples were single clone in nature on the basis of pvrbp-2 RFLP analysis. Plasmid was purified using plasmid extraction kits (MDI, India) and purified plasmids were sequenced commercially (Macrogen Inc, Seoul, Korea) [24]. For DNA sequencing, each plasmid was sequenced with forward, reverse and internal primers.
DNA Lasergene software 7.1 (DNA Star Inc., USA) was used for editing raw DNA sequences (EditSeq module), with SeqMan module used for contig formation and ClustalW module for sequences alignment. DNA sequences of $p v r b p-2$ obtained from field isolates of $P$. vivax were deposited in GenBank (JN872360-JN872372).

\section{Results}

Identification of genetic polymorphism using

\section{PCR-RFLP method}

A total of $90 P$. vivax samples were analyzed where in all samples gave single clear amplification of $\sim 2.0 \mathrm{~kb}$ fragment size and none of the PCR fragments showed size variation (Figure 3a). Amplified PCR fragment covers both coding and non-coding regions. The coding regions are marked by a 449-503 bp and 705-1946 bp

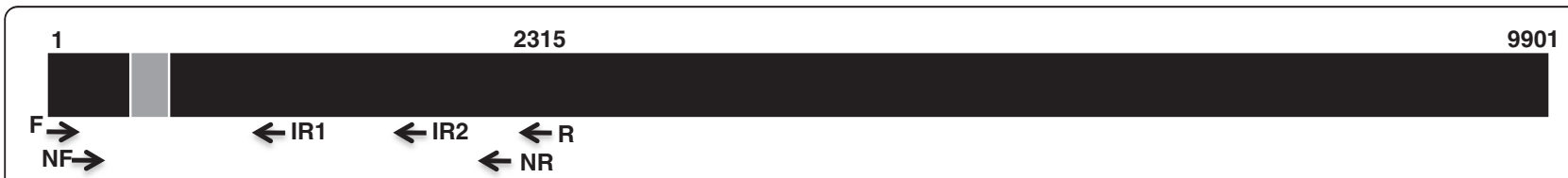

Figure 2 Diagrammatic representation of primers location on pvrbp-2 gene. Gray and black boxes indicate intron and exon respectively, and arrows indicate location of primers. F and R: forward and reverse primers of primary PCR respectively, NF and NR: forward and reverse primers of nested PCR respectively. IR1 and IR2 are internal sequencing primers. 


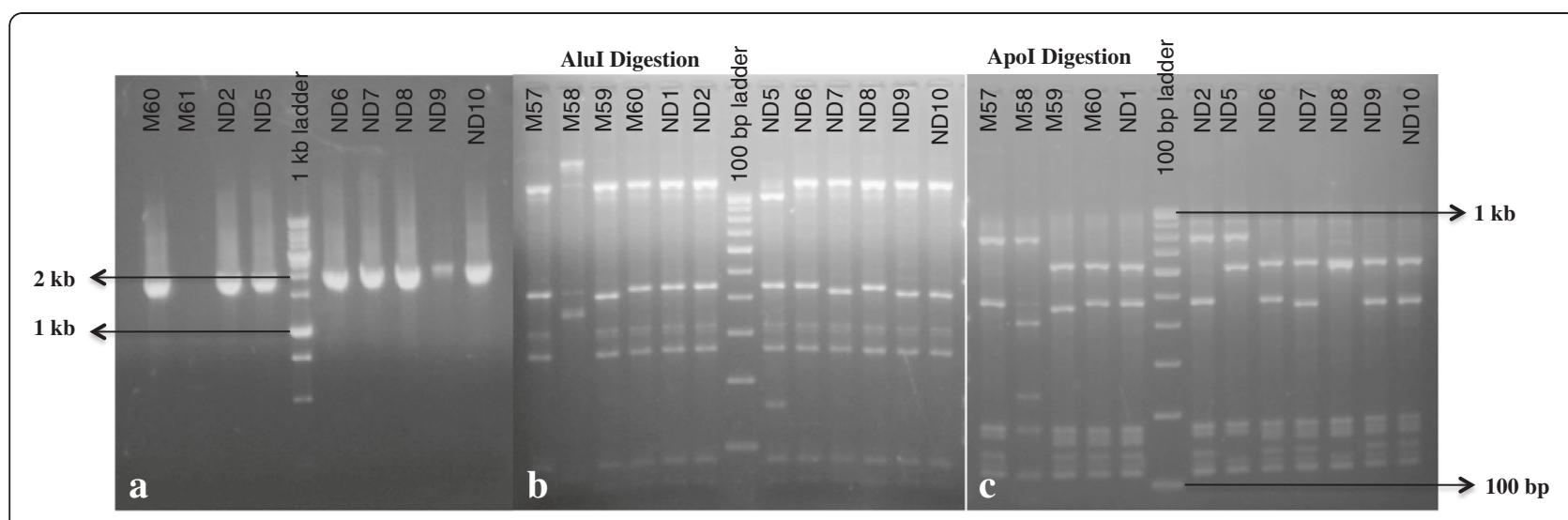

Figure 3 Gel pictures of PCR and RFLP of pvrbp-2 gene, a) PCR amplification, b) Alul digestion, c) Apol digestion. Name above the each well represents sample identity.

in the amplified PCR product (Figure 2). Virtual restriction mapping of pvrbp-2 sequence suggests the use of $A p o \mathrm{I}$ and $A l u \mathrm{I}$ restriction enzymes for RFLP analysis. Initially, five samples were digested with the above two enzymes to make sure that these enzymes can identify genetic polymorphism from field isolates. Interestingly, genetic polymorphism in AluI and ApoI digestion was observed in selected five samples. Further, PCR products obtained from 83 P. vivax isolates were digested with $A l u \mathrm{I}$ and ApoI enzymes separately. RFLP pattern of pvrbp-2 gene with $A l u \mathrm{I}$ and $A p o \mathrm{I}$ has been shown in figure $3 \mathrm{~b} \& \mathrm{c}$ respectively.

A substantial number of RFLP pattern for both enzymes were observed with respect to the Sal-1 strain based $p v r b p-2$ gene sequence. In total, 13 distinct $A l u \mathrm{I}$ and 30 distinct ApoI RFLP patterns were observed among 83 samples. RFLP analysis revealed mainly two distinct digestion patterns in field isolates by both enzymes. This suggests that each enzyme has two major types of digestion pattern. RFLP pattern of six samples was confirmed by DNA sequencing. Among six samples, DNA sequences of five samples were in agreement with RFLP data, however in a single sample (Pv-7) RFLP pattern of only ApoI enzyme was not matched. This may be due to the sequencing of only one clone from each cloning experiment. The numbers of RFLP pattern of individual enzymes from all samples are listed in Table 1. The frequencies of $A l u \mathrm{I}$ and $A p o \mathrm{I}$ genotypes varied in field isolates (Figure 4). Further, combination of $A l u \mathrm{I}$ and ApoI RFLP patterns revealed a total of 36 distinct haplotypes/genotypes suggesting a high degree of genetic diversity in $p v r b p-2$ sequences in the field isolates of $P$. vivax.

\section{Multiple infection and population genetic structure}

In brief, if a mono-infection sample (infection of single species) show a single genotype, it is denoted as single- clone infection, but if it shows more than one genotype, it is denoted as a multi-clone/multiple infection. RFLP analysis using $A l u \mathrm{I}$, showed seven isolates (8.43\%) to have multi-clone infection. In contrast, ApoI showed 13 isolates $(15.66 \%)$ as multi-clone infection. In total, 14 isolates $(16.86 \%)$ were observed to have multi-clone infection. Four multi-clone samples were having both Sal-1 and Belem alleles, however remaining ten multiclone isolates were infected with different genotypes of either Sal-1 or Belem alleles.

Genetic polymorphism was observed among all geographical regions of the Indian subcontinent. The total number of genotypes observed in Delhi, Nadiad, Panna, Rourkela, Chennai and Kamrup were 11, 14, 12, 7, 7 and 4 respectively. In every geographical region, genotypes were observed to be unique (local polymorphism) and shared in varied proportion (Figure 5). Allelic analysis shows a limited fraction of genotypes were observed to have been shared within $2-3$ populations. Only a single genotype (14) was observed in five geographical regions, however, none of the shared genotypes was observed between six geographical regions. This study suggests a diverse pool of pvrbp-2 repertoire in all geographical regions. This study also uncovered many unique $p v r b p-2$ genotypes to exist among geographical regions.

\section{DNA sequence polymorphism}

To understand and support the high degree of genetic diversity observed in PCR-RFLP analysis in pvrbp-2, 13 random samples (Nadiad; 7, Delhi; 1, Kamrup; 2, and Panna; 3) were sequenced, of which six isolates were RFLP analyzed. DNA sequence analysis also revealed a high degree of genetic polymorphism such as indels/tandem repeats and single nucleotide polymorphism (SNPs) among field isolates of $P$. vivax. Two indels were found which were restricted to non-coding region. The tandem repeat consisted of six amino acids (PA/TT/VQKK) 
Table 1 RFLP data and genotyping of Plasmodium vivax using pvrbp-2 gene

\begin{tabular}{|c|c|c|c|c|c|c|c|c|c|c|c|c|c|c|c|c|}
\hline \multirow{2}{*}{$\begin{array}{l}\text { Sample } \\
\mathrm{PV}-2\end{array}$} & \multicolumn{5}{|c|}{ Alul RFLP Pattern (bp) } & \multirow{2}{*}{$\begin{array}{c}\begin{array}{c}\text { Alul } \\
\text { Genotype }\end{array} \\
1\end{array}$} & \multirow{2}{*}{$\begin{array}{c}\begin{array}{c}\text { Combined Genotype/ } \\
\text { number of isolates }\end{array} \\
1 / 8\end{array}$} & \multirow{2}{*}{$\begin{array}{c}\begin{array}{c}\text { Apol } \\
\text { Genotype }\end{array} \\
1\end{array}$} & \multicolumn{8}{|c|}{ Apol RFLP Pattern (bp) } \\
\hline & 1200 & 410 & 280 & 90 & & & & & 650 & 450 & 180 & 170 & 160 & 140 & 120 & 80 \\
\hline Pv-7 & 1200 & 430 & 280 & 90 & & 2 & $2 / 2$ & 2 & 650 & 180 & 170 & 160 & 130 & 120 & & \\
\hline$P \vee-14$ & 1500 & 1200 & 410 & 380 & 280 & 3 & $3 / 1$ & 3 & 800 & 650 & 450 & 410 & 250 & 180 & 120 & \\
\hline ND-52 & 1500 & 380 & 80 & & & 4 & $4 / 2$ & 4 & 800 & 410 & 250 & 180 & 120 & 90 & & \\
\hline ND-51 & 1200 & 430 & 280 & 90 & & 2 & $5 / 5$ & 5 & 650 & 480 & 180 & 170 & 160 & 140 & 130 & 120 \\
\hline ND-54 & 1200 & 410 & 280 & 180 & 90 & 5 & $6 / 1$ & 6 & 650 & 450 & 180 & 170 & 160 & 140 & 130 & 120 \\
\hline M-53 & 1500 & 380 & & & & 6 & $7 / 3$ & 7 & 800 & 410 & 250 & 180 & 120 & & & \\
\hline$M-54$ & 1200 & 430 & 380 & 90 & & 7 & $8 / 1$ & 7 & 800 & 410 & 250 & 180 & 120 & & & \\
\hline M-55 & 1200 & 430 & 280 & 90 & & 2 & $9 / 1$ & 8 & 850 & 800 & 750 & 180 & 170 & 120 & 80 & \\
\hline ND-57 & 1000 & 430 & 280 & 180 & 90 & 8 & $10 / 2$ & 9 & 800 & 650 & 180 & 170 & 120 & & & \\
\hline RR-1 & 1200 & 430 & 280 & 90 & & 2 & $11 / 2$ & 10 & 800 & 480 & 180 & 170 & 140 & 120 & 80 & \\
\hline RR-18 & 1200 & 430 & 380 & 80 & & 7 & $12 / 1$ & 11 & 650 & 450 & 250 & 180 & 160 & 120 & 90 & \\
\hline M-51 & 1200 & 430 & 280 & 90 & & 2 & $13 / 1$ & 12 & 650 & 180 & 170 & 160 & 130 & 120 & 80 & \\
\hline M-57 & 1200 & 410 & 280 & 90 & & 1 & $14 / 2$ & 13 & 800 & 480 & 180 & 170 & 140 & 120 & & \\
\hline M-58 & 1500 & 380 & & & & 6 & $15 / 10$ & 14 & 800 & 410 & 250 & 180 & 120 & 80 & & \\
\hline M-59 & 1200 & 410 & 280 & 90 & & 1 & $16 / 4$ & 15 & 650 & 450 & 180 & 170 & 160 & 140 & 120 & \\
\hline ND-1 & 1200 & 430 & 280 & 90 & & 2 & $17 / 3$ & 16 & 650 & 480 & 180 & 170 & 160 & 140 & 120 & \\
\hline ND-2 & 1200 & 430 & 280 & 90 & & 2 & $18 / 1$ & 13 & 800 & 480 & 180 & 170 & 140 & 120 & & \\
\hline ND-8 & 1200 & 430 & 280 & 90 & & 2 & $19 / 1$ & 17 & 650 & 180 & 170 & 160 & 120 & & & \\
\hline ND-12 & 1200 & 430 & 280 & 90 & & 2 & $20 / 1$ & 18 & 800 & 650 & 180 & 170 & 130 & 120 & & \\
\hline ND-14 & 1200 & 430 & 410 & 280 & 90 & 9 & $21 / 1$ & 19 & 800 & 650 & 450 & 180 & 170 & 140 & 130 & 120 \\
\hline ND-29 & 1500 & 380 & 80 & & & 4 & $22 / 10$ & 14 & 800 & 410 & 250 & 180 & 120 & 80 & & \\
\hline$P-5$ & 1500 & 380 & 80 & & & 4 & $23 / 1$ & 21 & 650 & 410 & 250 & 180 & 160 & 120 & 80 & \\
\hline R-12 & 1200 & 410 & 280 & 90 & & 1 & $24 / 2$ & 22 & 650 & 600 & 180 & 170 & 160 & 120 & & \\
\hline R-18 & 1200 & 430 & 280 & 90 & & 2 & $25 / 2$ & 23 & 800 & 480 & 180 & 170 & 140 & 130 & 120 & \\
\hline A-385 & 1500 & 1200 & 430 & 380 & 280 & 10 & $26 / 1$ & 24 & 800 & 650 & 410 & 250 & 180 & 170 & 120 & \\
\hline R-37 & 1200 & 430 & 280 & 90 & & 2 & $27 / 1$ & 25 & 800 & 650 & 480 & 180 & 170 & 120 & & \\
\hline D1 & 1200 & 410 & 280 & 90 & & 1 & $28 / 2$ & 6 & 650 & 450 & 180 & 170 & 160 & 140 & 130 & 120 \\
\hline D5 & 1200 & 430 & 280 & 90 & & 2 & $29 / 2$ & 26 & 650 & 600 & 180 & 170 & 160 & 130 & 120 & \\
\hline S2 & 1500 & 380 & & & & 6 & $30 / 2$ & 27 & 800 & 650 & 250 & 180 & 120 & & & \\
\hline S4 & 1200 & 430 & 280 & 90 & & 2 & $31 / 1$ & 28 & 650 & 450 & 180 & 170 & 160 & 140 & 130 & 120 \\
\hline C1 & 1200 & 410 & 280 & 90 & & 1 & $32 / 1$ & 29 & 600 & 180 & 170 & 160 & 130 & 120 & & \\
\hline$C 2$ & 1200 & 410 & 280 & 90 & & 1 & $33 / 1$ & 28 & 600 & 450 & 180 & 170 & 160 & 140 & 130 & 120 \\
\hline C5 & 1200 & 430 & 380 & & & 11 & $34 / 1$ & 30 & 800 & 450 & 250 & 180 & 120 & 80 & & \\
\hline C6 & 1500 & 1200 & 430 & 410 & 280 & 12 & $35 / 2$ & 3 & 800 & 650 & 450 & 410 & 250 & 180 & 120 & 80 \\
\hline C8 & 1200 & 400 & 380 & & & 13 & $36 / 1$ & 14 & 800 & 410 & 250 & 180 & 120 & 80 & & \\
\hline
\end{tabular}

revealed as $0-3$ repeats in field isolates. A total of 178 SNPs were found, out of which 32 were in non-coding region while the remaining were in coding region. The observed higher number of SNPs was mainly due to the dimorphism between Sal-1 and Belem type alleles. Number of non-synonymous substitutions in coding region was higher $(n=106)$ as compared to synonymous substitutions $(\mathrm{n}=46)$, which indicates that $p v r b p-2$ is under positive selection pressure. None of the SNP (synonymous or non synonymous) was associated with frame shift mutation. Comparison of $p v r b p-2$ sequences from Indian field isolates with $p v r b p-2$ reference sequence (Sal-1: P. vivax strain) suggests a higher degree of DNA sequence polymorphism. 


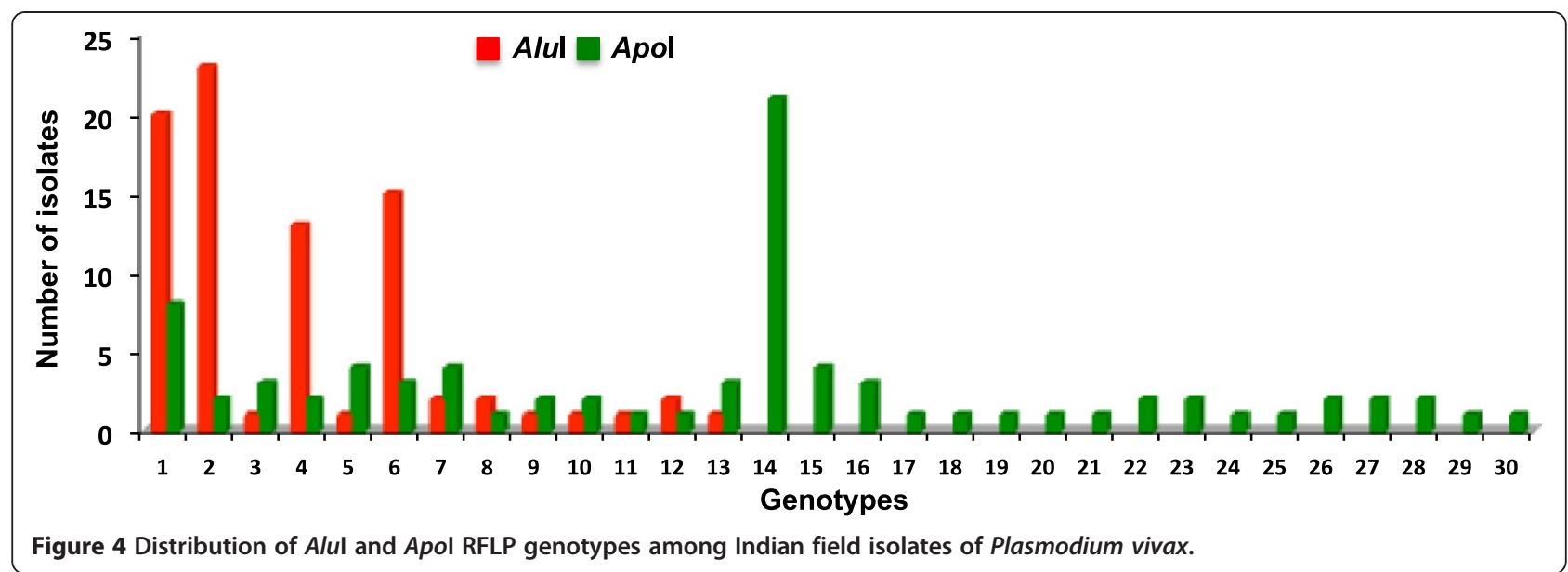

\section{Distinguishing Belem and Sal-1 alleles with RFLP}

The virtual restriction mapping of pvrbp-2 sequences AluI and ApoI enzymes reveals a distinct RFLP pattern of Belem and Sal-1 alleles. Virtual restriction mapping of pvrbp-2 with AluI revealed a distinct $1500 \mathrm{bp}$ and 380 bp fragments for Belem allele. Similarly, virtual restriction mapping with ApoI showed a distinct $250 \mathrm{bp}$ fragment for Belem allele. The results of virtual restriction mapping of Belem and Sal-1 pvrbp-2 sequences with $A l u \mathrm{I}$ and $A p o \mathrm{I}$ enzymes were confirmed with RFLP analysis of field isolates. On the basis of RFLP patterns, all samples were categorized according to the Sal-1 and Belem type. Of the 83 P. vivax isolates analyzed, 38.55\% (32/83) were Belem type, 56.63\% (47/83) were Sal-1 type, and $4.82 \%(4 / 83)$ were mixed of both alleles (Table 2). Furthermore, comparison of RFLP pattern showed Sal-1 alleles to be more polymorphic (24/36) than Belem allele $(12 / 36)$ in the natural parasite populations. Thus, dimorphism observed in sequence analysis could also be identified by simple PCR-RFLP method.

\section{Discussion}

Malaria eradication program is facing remarkable challenges due to spread of drug resistance and the complex population genetic structure of human malaria parasites. Gaining an insight into the genetic population structure of the parasites would provide valuable information for designing an improved malaria control strategy. The present study investigates genetic polymorphism in pvrbp-2 among field isolates of $P$. vivax using simple PCR-RFLP.

This is the first population based study of pvrbp-2 gene which revealed a high degree of polymorphism in field isolates of $P$. vivax. The sequence polymorphism reported in pvrbp-2 from four strains of $P$. vivax including Sal-1 and Belem [22] is supporting the extent of genetic polymorphism observed in pvrbp-2 in Indian isolates. The sequences of pvrbp-2 have shown a distinct dimorphism between Sal-1 and Belem alleles [22]. The dimorphism between Sal-1 and Belem strains of $P$. vivax has been reported earlier on the basis of pvmsp-1 [25]

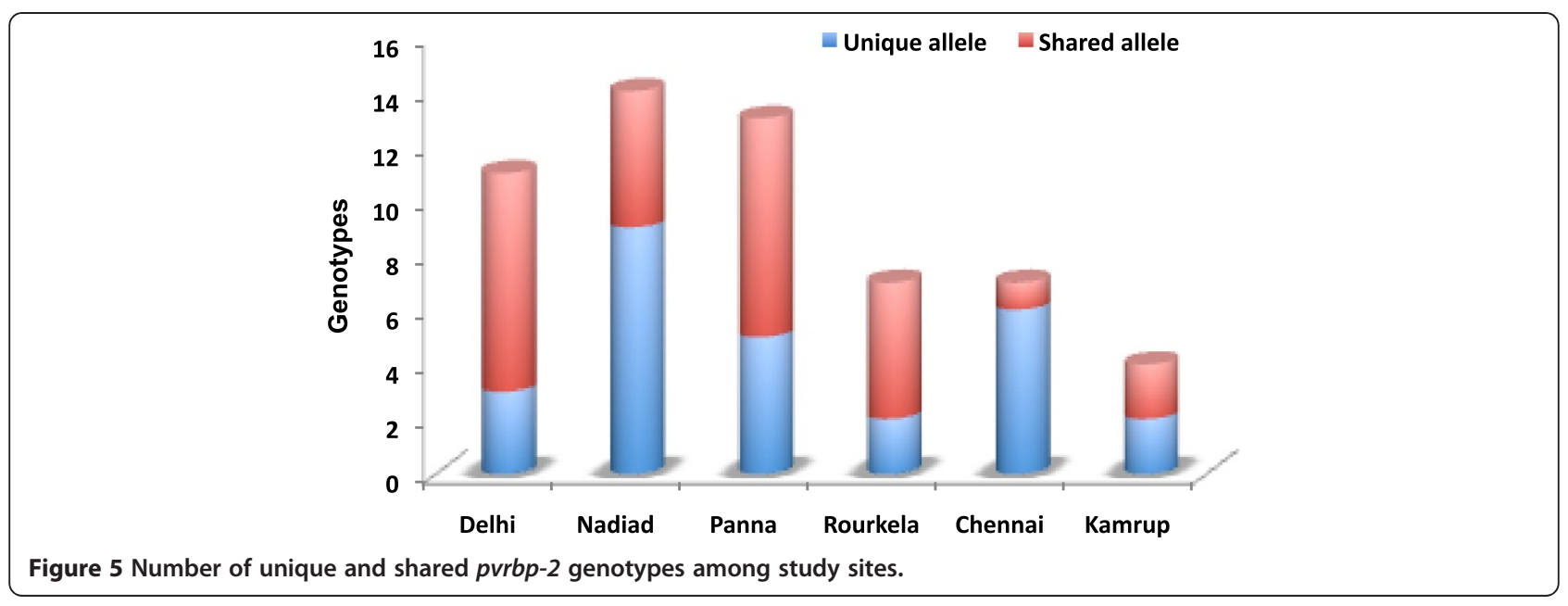




\begin{tabular}{lcccc}
$\begin{array}{l}\text { Table } 2 \\
\text { alleles in field isolates }\end{array}$ \\
$\begin{array}{l}\text { Geographical } \\
\text { regions }\end{array}$ & $\begin{array}{l}\text { Sample } \\
\text { size (N) }\end{array}$ & Sal-I & Belem & Both \\
\hline Delhi & 13 & 8 & 5 & \\
Nadiad & 21 & 17 & 4 & \\
Panna & 18 & 7 & 11 & \\
Rourkela & 16 & 10 & 4 & 2 \\
Chennai & 10 & 3 & 5 & 2 \\
Kamrup & 5 & 2 & 3 & \\
Total (n) & 83 & 47 & 32 & 4 \\
\hline & & & &
\end{tabular}

and the distinction between Sal-1 and Belem strains is entirely based on geographical location and allelic variation. The RFLP analysis of the present study using AluI and ApoI enzymes revealed a high degree of genetic polymorphism among field isolates which was further supported by pvrbp-2 nucleotide sequence polymorphism data. From RFLP analysis, it is clear that ApoI is identifying larger extent of genetic polymorphism in field isolates compared to AluI. This suggests that under limited resources, ApoI alone can be used to resolved larger extent of existing genetic variation in pvrbp-2 in the field isolates. The genetic polymorphism displayed by various antigen-encoding genes and biochemical marker in Indian field isolates of $P$. vivax [26-32] is also supported by the genetic polymorphism observed in pvrbp- 2 .

Plasmodium vivax isolates from Indian subcontinent represents diverse pool of genetic variants such as Belem and Chesson alleles in pvgam-1 [23], Belem and Sal-1 alleles in pvmsp-1 [30], and VK210 and VK247 in pvcsp [30]. Though, pvrbp-2 based Sal-1 and Belem alleles have not been identified from natural parasite populations, however present study uncovered both alleles in Indian $P$. vivax populations. As like other above genetic markers, pvrbp-2 also harbors both Sal-1 and Belem alleles in Indian populations however, their proportion varied between geographical regions.

Pvrbp-2 is a promising vaccine target for the development of effective anti-malarial control measure [20]. Identifying allelic polymorphism in pvrbp-2 within and between populations would certainly improve and extend the existing knowledge for development of anti-malaria control measure. The significance of this prospective study would be to uncover maximum number of hidden polymorphism. Several studies in recent past have shown many polymorphic forms in local population $[10,12,31,33]$. This study revealed genetic polymorphism in $P$. vivax populations which have been rarely shared between more than two populations which suggests that in the natural population, pvrbp-2 is diverse and this calls for thorough care to be taken while designing any anti-malarial strategy targeting $p v r b p-2$.

\section{Conclusions}

The study suggests that pvrbp-2 is highly polymorphic genetic marker which can be used for population genetic analyses. RFLP analysis suggests presence of nearly similar proportion of Sal-1 and Belem alleles in Indian $P$. vivax populations. The larger extent of genetic polymorphism identified from limited samples advocates to screen genetic polymorphism in pvrbp-2 from malaria endemic geographical regions and countries for designing pvrbp-2 based anti-malarial control measures.

\section{Additional file}

Additional file 1: Detail information about study sites.

\section{Competing interests}

Authors declare that they don't have competing interests.

\section{Author's contribution}

SKP: Conceptual designing, experimental design and work, data analysis and manuscript writing, PK: Experimental work and data compilation, OPS: Overall supervision and manuscript writing. All authors read and approved the final manuscript.

\section{Acknowledgements}

This work was supported by the Indian Council of Medical Research, New Delhi, India (ICMR-Centenary Postdoctoral Award). This study was also partially supported with funds from a Fogarty International Center Global Infectious Disease training grant (D43 TW007884). The content of this manuscript is solely the responsibility of the authors and does not necessarily represent the official views of the Fogarty International Center or the National Institutes of Health. SKP is an ICMR-Centenary Postdoctoral Fellow. The authors are thankful to Cherry L. Dykes for editorial correction. The authors would like to thank NIMR scientists, staffs (Molecular Biology Division) and field units for their support and cooperation during the study.

Received: 15 July 2012 Accepted: 19 October 2012

Published: 24 October 2012

\section{References}

1. Andrade BB, Reis-Filho A, Souza-Neto SM, Clarencio J, Camargo LM, Barral A, Barral-Netto M: Severe Plasmodium vivax malaria exhibits marked inflammatory imbalance. Malar J 2010, 9:13.

2. Kochar DK, Das A, Kochar SK, Saxena V, Sirohi P, Garg S, Kochar A, Khatri MP, Gupta V: Severe Plasmodium vivax malaria: a report on serial cases from Bikaner in northwestern India. AmJTrop Med Hyg 2009, 80(2):194-198.

3. Kochar DK, Saxena V, Singh N, Kochar SK, Kumar SV, Das A: Plasmodium vivax malaria. Emerg Infect Dis 2005, 11(1):132-134.

4. Genton B, D'Acremont V, Rare L, Baea K, Reeder JC, Alpers MP, Muller I: Plasmodium vivax and mixed infections are associated with severe malaria in children: a prospective cohort study from Papua New Guinea. PLoS Med 2008, 5(6):e127.

5. Rogerson SJ, Carter R: Severe vivax malaria: newly recognised or rediscovered. PLoS Med 2008, 5(6):e136.

6. Tjitra E, Anstey NM, Sugiarto P, Warikar N, Kenangalem E, Karyana M, Lampah DA, Price RN: Multidrug-resistant Plasmodium vivax associated with severe and fatal malaria: a prospective study in Papua. Indonesia. PLoS Med 2008, 5(6):e128.

7. Mendis K, Sina BJ, Marchesini P, Carter R: The neglected burden of Plasmodium vivax malaria. AmJTrop Med Hyg 2001, 64(1-2 Suppl):97-106.

8. Imwong M, Sudimack D, Pukrittayakamee S, Osorio L, Carlton JM, Day NP, White NJ, Anderson TJ: Microsatellite variation, repeat array length, and population history of Plasmodium vivax. Mol Biol Evol 2006, 23(5):1016-1018.

9. Karunaweera ND, Ferreira MU, Munasinghe A, Barnwell JW, Collins WE, King CL, Kawamoto F, Hartl DL, Wirth DF: Extensive microsatellite diversity 
in the human malaria parasite Plasmodium vivax. Gene 2008, 410(1):105-112.

10. Figtree M, Pasay CJ, Slade R, Cheng Q, Cloonan N, Walker J, Saul A: Plasmodium vivax synonymous substitution frequencies, evolution and population structure deduced from diversity in AMA 1 and MSP 1 genes. Mol Biochem Parasitol 2000, 108(1):53-66.

11. Rayner JC, Corredor V, Feldman D, Ingravallo P, Iderabdullah F, Galinski MR, Barnwell JW: Extensive polymorphism in the plasmodium vivax merozoite surface coat protein MSP-3alpha is limited to specific domains. Parasitology 2002, 125(Pt 5):393-405.

12. Cole-Tobian J, King CL: Diversity and natural selection in Plasmodium vivax Duffy binding protein gene. Mol Biochem Parasitol 2003, 127(2):121-132.

13. Kitchen SF: The infection of reticulocytes by Plasmodium vivax. AmJTrop Med Hyg 1938, 18:347-353.

14. Pasvol G, Weatherall DJ, Wilson RJ: The increased susceptibility of young red cells to invasion by the malarial parasite Plasmodium falciparum. Br J Haematol 1980, 45(2):285-295.

15. Mitchell GH, Hadley TJ, McGinniss MH, Klotz FW, Miller LH: Invasion of erythrocytes by Plasmodium falciparum malaria parasites: evidence for receptor heterogeneity and two receptors. Blood 1986, 67(5):1519-1521.

16. Rayner JC, Huber CS, Galinski MR, Barnwell JW: Rapid evolution of an erythrocyte invasion gene family: the Plasmodium reichenowi Reticulocyte Binding Like (RBL) genes. Mol Biochem Parasitol 2004, 133(2):287-296.

17. Galinski MR, Medina CC, Ingravallo P, Barnwell JW: A reticulocyte-binding protein complex of Plasmodium vivax merozoites. Cell 1992, 69(7):1213-1226.

18. Keen JK, Sinha KA, Brown KN, Holder AA: A gene coding for a highmolecular mass rhoptry protein of Plasmodium yoelii. Mol Biochem Parasitol 1994, 65(1):171-177.

19. Rayner JC, Galinski MR, Ingravallo P, Barnwell JW: Two Plasmodium falciparum genes express merozoite proteins that are related to Plasmodium vivax and Plasmodium yoelii adhesive proteins involved in host cell selection and invasion. Proc Natl Acad Sci U S A 2000, 97(17):9648-9653.

20. Galinski MR, Barnwell JW: Plasmodium vivax: Merozoites, invasion of reticulocytes and considerations for malaria vaccine development. Parasitol Today 1996, 12(1):20-29.

21. Plasmodium Genome Database. www.plasmodb.org

22. Rayner JC, Tran TM, Corredor V, Huber CS, Barnwell JW, Galinski MR Dramatic difference in diversity between Plasmodium falciparum and Plasmodium vivax reticulocyte binding-like genes. AmJTrop Med Hyg 2005, 72(6):666-674.

23. Prajapati SK, Verma A, Adak T, Yadav RS, Kumar A, Eapen A, Das MK, Singh $N$, Sharma SK, Rizvi MA, et al: Allelic dimorphism of Plasmodium vivax gam-1 in the Indian subcontinent. Malar J 2006, 5:90.

24. Korea: Macrogen Inc; http://www.macrogen.com

25. Kolakovich KA, Ssengoba A, Wojcik K, Tsuboi T, al-Yaman F, Alpers M, Adams $\mathrm{H}$ : Plasmodium vivax: favored gene frequencies of the merozoite surface protein-1 and the multiplicity of infection in a malaria endemic region. Exp Parasitol 1996, 83(1):11-19.

26. Joshi $\mathrm{H}$ : Markers for population genetic analysis of human plasmodia species. P. falciparum and P. vivax. J Vector Borne Dis 2003, 40(3-4):78-83.

27. Joshi H, Prajapati SK, Verma A, Kang'a S, Carlton JM: Plasmodium vivax in India. Trends Parasitol 2008, 24(5):228-235.

28. Joshi H, Subbarao SK, Adak T, Nanda N, Ghosh SK, Carter R, Sharma VP: Genetic structure of Plasmodium vivax isolates in India. Trans $R$ Soc Trop Med Hyg 1997, 91(2):231-235

29. Joshi H, Subbarao SK, Raghavendra K, Sharma VP: Plasmodium vivax: enzyme polymorphism in isolates of Indian origin. Trans $R$ Soc Trop Med Hyg 1989, 83(2):179-181.

30. Kim JR, Imwong M, Nandy A, Chotivanich $K$, Nontprasert A, Tonomsing $N$, Maji A, Addy M, Day NP, White NJ, et al: Genetic diversity of Plasmodium vivax in Kolkata. India. Malar J 2006, 5:71.

31. Prajapati SK, Joshi H, Dua VK: Antigenic repertoire of Plasmodium vivax transmission-blocking vaccine candidates from the Indian subcontinent Malar J 2011, 10:111.
32. Prajapati SK, Joshi $H$, Valecha N: Plasmodium vivax merozoite surface protein-3 alpha: a high-resolution marker for genetic diversity studies. $J$ Vector Borne Dis 2010, 47(2):85-90.

33. Grynberg P, Fontes CJ, Hughes AL, Braga EM: Polymorphism at the apical membrane antigen 1 locus reflects the world population history of Plasmodium vivax. BMC Evol Biol 2008, 8:123.

doi:10.1186/1471-2180-12-243

Cite this article as: Prajapati et al:: Molecular analysis of reticulocyte binding protein-2 gene in Plasmodium vivax isolates from India. BMC Microbiology 2012 12:243.

\section{Submit your next manuscript to BioMed Central and take full advantage of:}

- Convenient online submission

- Thorough peer review

- No space constraints or color figure charges

- Immediate publication on acceptance

- Inclusion in PubMed, CAS, Scopus and Google Scholar

- Research which is freely available for redistribution 